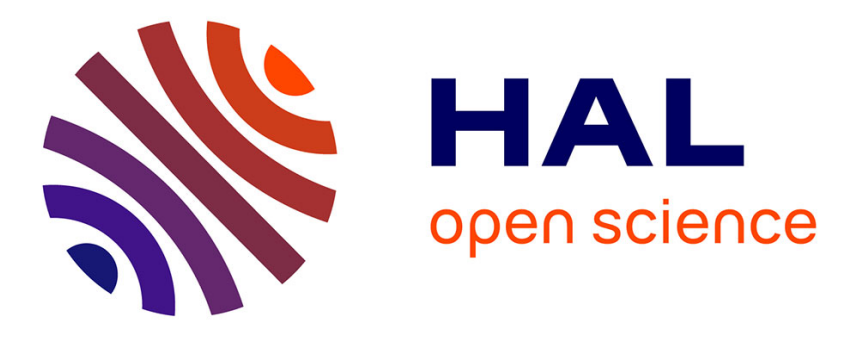

\title{
Biosynthesis of gold nanoparticles by the living freshwater diatom Eolimna minima, a species developed in river biofilms.
}

\author{
Agnès Feurtet-Mazel, Stéphane Mornet, Laëtitia Charron, Nathalie \\ Mesmer-Dudons, Régine Maury-Brachet, Magalie Baudrimont
}

\section{To cite this version:}

Agnès Feurtet-Mazel, Stéphane Mornet, Laëtitia Charron, Nathalie Mesmer-Dudons, Régine MauryBrachet, et al.. Biosynthesis of gold nanoparticles by the living freshwater diatom Eolimna minima, a species developed in river biofilms.. Environmental Science and Pollution Research, 2016, 23 (5), pp.4334-4339. 10.1007/s11356-015-4139-x . hal-01282833

\section{HAL Id: hal-01282833 \\ https://hal.science/hal-01282833}

Submitted on 21 Jan 2021

HAL is a multi-disciplinary open access archive for the deposit and dissemination of scientific research documents, whether they are published or not. The documents may come from teaching and research institutions in France or abroad, or from public or private research centers.
L'archive ouverte pluridisciplinaire HAL, est destinée au dépôt et à la diffusion de documents scientifiques de niveau recherche, publiés ou non, émanant des établissements d'enseignement et de recherche français ou étrangers, des laboratoires publics ou privés. 


\title{
Biosynthesis of gold nanoparticles by the living freshwater diatom Eolimna minima, a species developed in river biofilms
}

\author{
Agnès Feurtet-Mazel • Stéphane Mornet • \\ Laëtitia Charron • Nathalie Mesmer-Dudons • \\ Régine Maury-Brachet • Magalie Baudrimont
}

\begin{abstract}
Testing biotransformation capacities of living aquatic microalgae diatoms to naturally synthetize gold nanoparticles (AuNP) from gold salts and assessing aftereffects on their viability by microscope observations is a great challenge. In this work, a laboratory experiment was conducted, which aimed to observe (i) directly by transmission electronic and light microscopy and (ii) through indirect measurements (UVvisible spectroscopy) the periphytic freshwater diatom Eolimna minima exposed to gold salts. This work revealed the capacity of E. minima to intracellularly biosynthetize AuNP and to tolerate it. AuNP synthesis appears as a mechanism of detoxification to protect diatom from gold salt contamination. We also pointed out the risks associated with the spread of diatoms full of AuNP, through the trophic web of freshwater ecosystems. The preponderant part of the diatoms in natural biofilms associated with their position at the basis of the trophic webs in rivers could then make them responsible for the contamination of their consumers (grazer animals) and consequently for the potential release of AuNP through the entire food web.
\end{abstract}

Keywords Periphytic microalgae $\cdot$ Diatom $\cdot$ Aquatic environment $\cdot$ Biomineralization of gold salts $\cdot$ Gold nanoparticles $\cdot$ Contamination $\cdot$ Microscopy $\cdot$ Laboratory experiment

Responsible editor: Philippe Garrigues

A. Feurtet Mazel $(\bowtie) \cdot$ L. Charron $\cdot$ N. Mesmer Dudons

R. Maury Brachet $\cdot M$. Baudrimont

Univ. Bordeaux, EPOC, UMR 5805, 33120 Arcachon, France

e mail: agnes.feurtet mazel@u bordeaux.fr

S. Mornet

CNRS, ICMCB, UPR 9048, 33600 Pessac, France

\section{Introduction}

For more than 30 years, nanosciences and technologies have explored the fields of the infinitely small, and the technological developments here are concomitant with an increasing demand by biotech industries looking for new products from electronic components to medical applications in biomaterials, automobiles, and a great diversity of consumer products (cosmetology, paint...). However, the industrial synthesis of nanoobjects, as for chemical synthesis, is a source of environmental pollution via the numerous chemicals used in their synthesis. Development of new and clean nanotechnology manufacturing approaches which minimize potential environmental and human health risks is a challenge which motivates the scientific community (Guowu et al. 2011; Narayanan and Sakthivel 2011; Korbekandi et al. 2009).

The use of microorganisms as nanofactories has been recently considered (Thakkar et al. 2010; Zhang et al. 2011; He et al. 2008; Mohanpuria et al. 2007; Gericke and Pinches 2006; Mandal et al. 2006). In aquatic environments, Singaravelu et al. (2007) then Govindaraju et al. (2009) took an interest in the capacity of the marine alga, Sargassum, to synthesize gold nanoparticles (NP) by an extracellular path, but few studies have focused on synthesis in living organisms (Gong et al. 2011; Schröfel et al. 2011; Brayner et al. 2007; Gardea-Torresdey et al. 2002). Identification of such a biological model, able to live, thrive, and reproduce while producing nanoparticles, could be a great help in promoting green NP synthesis. Terrestrial organisms exposed to very high metal concentrations (Moradi et al. 2010; Barbaroux et al. 2009) are known to highly concentrate the metal in their tissues, all the while prospering. Similar behavior might exist in organisms exposed to nanoparticles. Additionally, there is increasing evidence that engineered particles could pose an important risk to the environment and human life. Gold particles have widespread uses; they are one of the six major nanomaterials 
included in traded products (massive use in cosmetics, paint, coatings...) thanks to their optical and optoelectronic properties (Corti et al. 2007). They are the topic of numerous fundamental research studies in nanosciences, especially in plasmonics, photonics, metamaterials, or catalysis (LizMarzan 2004). In more applied fields, they have proven to be very useful in genomics, as biomedical imaging contrast agents in tomography X-rays, as a platform of vectorization of drug molecules, as well as in radiotherapy (Berbeco et al. 2011). And owing to the strong electron density of gold, detection of gold nanoparticles is possible by transmission electronic microscopy (TEM) (Xu et al. 2006), making them thus very useful in cellular imaging. On the other hand, there is very little work on the impact of gold nanoparticles (AuNP) on human beings or aquatic organisms (Von Moos et al. 2014; Tedesco et al. 2010, 2008).

Thus, progress in nanotechnologies must be accompanied by awareness of the potential environmental and toxic impact of nanomaterials (Oberdörster et al. 2005), which may end up in natural aquatic environments via industrial effluents or consumer use, and there interfere with the dynamics among the trophic levels of natural ecosystems. For example Renault et al. (2008) showed the toxic effect of AuNP in two species (the green microalga Scenedesmus subspicatus and the bivalve Corbicula fluminea) and the trophic transfer of AuNP between these two species.

Work concerning nanomaterial synthesis and work focused on the potential risks incurred by NP dispersion in the environment are almost always tackled separately. In order to jointly consider both of these aspects of nanomaterials, and to pursue research into nanomaterials which are more environmentally friendly throughout their lifecycle, this work has a double objective: (i) testing the biotransformation capacities of living microalgae diatoms to naturally synthetize AuNP from gold salts, and (ii) assessing the aftereffects of this biotransformation on the viability of these diatoms. In this work, we conclude that living diatoms have a good capacity to biosynthesize AuNP inside their cellular milieu. Possible detoxification mechanisms by diatoms are evoked to explain this synthesis, which might occur as a protection reaction to the presence of gold salts. We also point out the potential risks associated with the spread of diatoms full of AuNP through the trophic web of freshwater ecosystems.

\section{Material and methods}

\section{Diatom species studied}

The biological model is a freshwater microalga (E. minima, length 5-18 $\mu \mathrm{m}$ ) of the diatom group (Pennales, Biraphidae), well known for the architecture and nanometric ornamentation of their two siliceous valves called frustule protecting their inner cellular content (Fig. 1). Diatoms generate their cell walls by silica biomineralization. The cell walls are composed of silica and organic macromolecules and different atomic force microscopy (AFM) techniques show a complex microscopic structure with a nanostructured granular surface (Noll et al. 2002). Diatoms produce exudates through their frustule which constitute a coating of extracellular polymeric substances (Gélabert et al. 2004, 2007; Pokrovsky et al. 2010) and agglomerate to bacteria, fungi, protozoa, and other microalgae, to form cohesive biofilms on any support immersed in running waters and are consumed by various trophic levels of the aquatic ecosystem. They are responsible for a large proportion of vegetal primary production in upstream watercourses because of their short development cycles (a few hours to a few days by mainly asexual reproduction) and their ubiquity. E. minima development is therefore the basis of the functioning of aquatic food webs. This is a cosmopolite species, recorded all over the world but particularly in organic rich and/or polluted aquatic environments, and is therefore considered a resistant species. It develops by adhering to the substrate and is one of the pioneer species involved in the elaboration of a biofilm. Its selection in this study appears therefore justified to answer our double objective of looking for AuNP biosynthesis in living diatoms and looking for effects of AuNP in the aquatic food web.

Exposure of the diatom E. minima to contaminant solution

An axenic strain of $E$. minima was obtained from the Culture Collection of Algae (UTEX, Austin, USA), and it was cultured in suspension in $3 \mathrm{~L}$ Erlenmeyer flasks in the laboratory at $20^{\circ} \mathrm{C}$ in sterile Dauta culture medium (Dauta 1982) modified by the addition of siliceous $\left(10 \mathrm{mg} \mathrm{L}^{-1}\right)$, at $\mathrm{pH} 7.7$. Flasks were kept in a thermoregulated chamber under a light intensity of $160 \mu \mathrm{mol}$ photon $\mathrm{m}^{-2} \mathrm{~s}^{-1}$ and 12:12 light/dark cycle to favor diatom growth.

E. minima diatom suspensions were exposed in $50 \mathrm{~mL}$ polypropylene tubes under axenic conditions to potassium gold (III) chloride ( $\mathrm{KAuCl}_{4}, 99.995 \%$, Sigma Aldrich) at three concentrations $(20 \mu \mathrm{g} / \mathrm{mL}$ : NP20; $50 \mu \mathrm{g} / \mathrm{mL}$ : NP50;

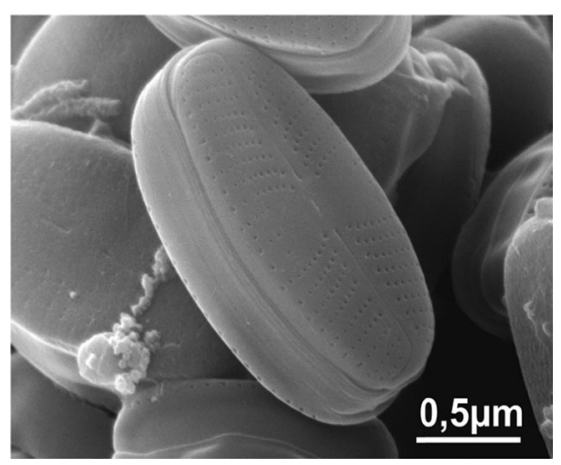

Fig. 1 SEM image of Eolimna minima 
$100 \mu \mathrm{g} / \mathrm{mL}: \mathrm{NP} 100$ ) and were sampled twice (one day after $t_{0}$ contamination: $t_{1}$, then 7 days: $t_{7}$ ) looking for AuNP. pH was checked in all the samples at the start and end of the experiment.

Control tubes (Control20, Control50, and Control100) contained only culture medium and $\mathrm{KAuCl}_{4}$ solution at the three concentrations. During the experiment, each tube contained $1.2 \times 10^{6}$ cells $/ \mathrm{mL}$ of diatoms, in suspension in Dauta culture medium solution, exposed under a light intensity of $40 \mu \mathrm{mol}$ photon $\mathrm{m}^{-2} \mathrm{~s}^{-1}$, a temperature of $20^{\circ} \mathrm{C}$, and a photoperiod of $12 \mathrm{~L} / 12 \mathrm{D}$. AuNP production was verified after 7 days by UV-visible spectroscopy measurements between 400 and $800 \mathrm{~nm}$ with a UV-Schimadzu spectrophotometer (resolution $1 \mathrm{~nm}$ ) to detect AuNP peaks at $520 \mathrm{~nm}$. At both sampling times, whole diatoms were observed by light microscopy (Leitz Wetzlar). At sampling time $\left(t_{7}\right)$, histological diatom preparations obtained from $50-70 \mathrm{~nm}$ ultra thin cuts were prepared for observation by transmission electronic microscopy (TEM, Technaï 12, Phillips).

\section{Results}

$\mathrm{pH}$ during exposure

$\mathrm{pH}$ was checked in all the samples at the start and end of the experiment (Table 1). After 7 days of exposure, $\mathrm{pH}$ values did not change in control tubes without diatoms, but increased in the tubes containing diatoms in suspension while remaining in a $\mathrm{pH}$ range acceptable for them, E. minima being considered as an alkalophil diatom (Kovacs et al. 2006).

Evolution of the absorption spectra of the contaminant solutions to the different conditions of exposure

Diatom solutions from NP50 presented an absorption spectrum with a peak between 520 and $585 \mathrm{~nm}$, corresponding to the surface plasmon resonance of AuNP in formation (Fig. 2a). This peak signaled AuNP biosynthesis within the diatom solution, and was corroborated by visual observation of coloration (from light to red purple) at $t_{7}$; control and $t_{0}$ samples were uncolored. These observed surface plasmon

Table $1 \mathrm{pH}$ values at the beginning $\left(t_{0}\right)$ and at the end $\left(t_{7}\right)$ of the experiment

\begin{tabular}{lllllll}
\hline $\mathrm{pH}$ & $\mathrm{Ctrl} 20$ & $\mathrm{NP20}$ & $\mathrm{Ctrl} 50$ & $\mathrm{NP50}$ & $\mathrm{Ctrl} 100$ & $\mathrm{NP100}$ \\
\hline$t_{0}$ & 7.7 & 7.7 & 7.0 & 7.0 & 5.8 & 5.8 \\
$t_{7}$ & 7.6 & 9.7 & 7.1 & 7.9 & 5.7 & 7.3 \\
\hline
\end{tabular}

Control (Ctrl) 20, 50, and 100 (respectively 20,50, $100 \mu \mathrm{g} \mathrm{KAuCl}_{4} / \mathrm{mL}$ ) correspond to Dauta culture medium with $\mathrm{KAuCl}_{4}$ and no diatoms. $\mathrm{NP} 10,50$, and 100 (respectively 20,50,100 $\mu \mathrm{g} \mathrm{KAuCl}_{4} / \mathrm{mL}$ ) correspond to $\mathrm{KAuCl}_{4}$ solutions in Dauta medium with diatom suspensions

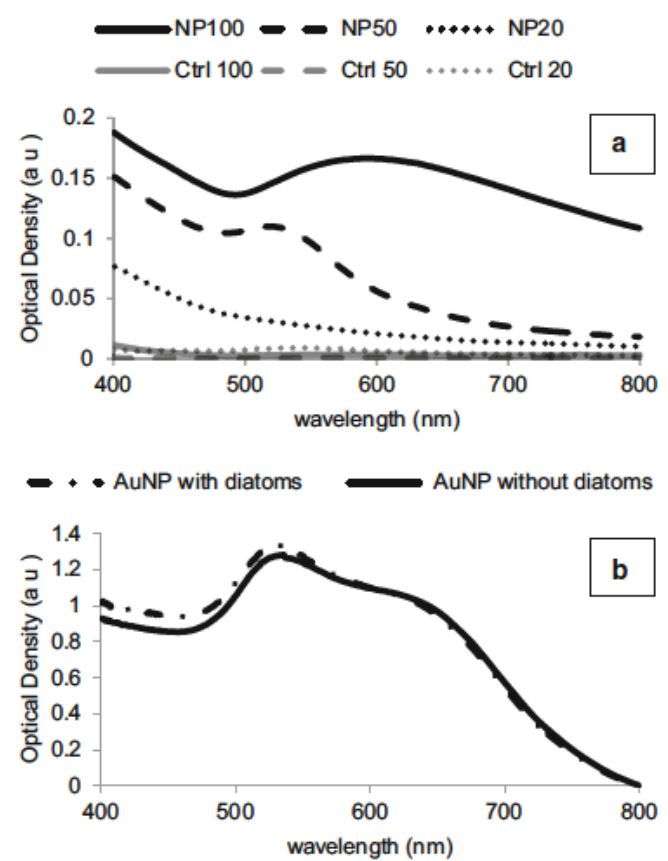

Fig. 2 Absorption spectra (between 400 and $800 \mathrm{~nm}$ ) a of the $\mathrm{KAuCl}_{4}$ solutions tested during the 7 day experiment: Control (Ctrl) 20,50, and 100 (respectively $20,50,100 \mu \mathrm{g} \mathrm{KAuCl} / 4 \mathrm{~mL}$ ) corresponding to Dauta culture medium with $\mathrm{KAuCl}_{4}$ and no diatoms; and $\mathrm{NP10}, 50$, and 100 solutions (respectively $20,50,100 \mu \mathrm{g} \mathrm{KAuCl} / \mathrm{mL}$ ) corresponding to $\mathrm{KAuCl}_{4}$ solutions in Dauta medium with diatom suspensions; $\mathbf{b}$ of an artificially prepared mixture of AuNP with or without diatoms

band are due to the interaction of the light with surface conduction electron of the gold nanoparticles. This band which appears for small particles with sizes from around $5 \mathrm{~nm}$ to tens of nanometers is red shifted to the near IR domain and broadened when the size increases. The wide plasmon band with a maximum of around $585 \mathrm{~nm}$ confirms the presence of large particles of gold with magnitude order of $100 \mathrm{~nm}$ or particles aggregates.

\section{Microscopic observations of E. minima}

Microscopic observations complemented the optical density (O.D.) values supporting AuNP biosynthesis in diatom solutions in the presence of $\mathrm{KAuCl}_{4}$. After 7 days, light microscopy revealed a pronounced color within the diatom cells, with light pinkish-colored cells still showing their green chloroplasts at NP20 to uniformly dark pink cells at NP100 (Fig. 3). This gradient of color corresponds to the different aggregation stages and sizes of AuNP in formation, as confirmed by the red shift of the broad plasmon band at NP100. Transmission electron microscopy confirmed the presence of AuNP inside (and outside) the cells with AuNP size not quite homogeneous and ranging from a few nanometers to around $100 \mathrm{~nm}$ (Fig. 4). At the two lower concentrations (NP20 and NP50), AuNP were preferentially confined between the siliceous frustule and the plasma membrane with a more marked 


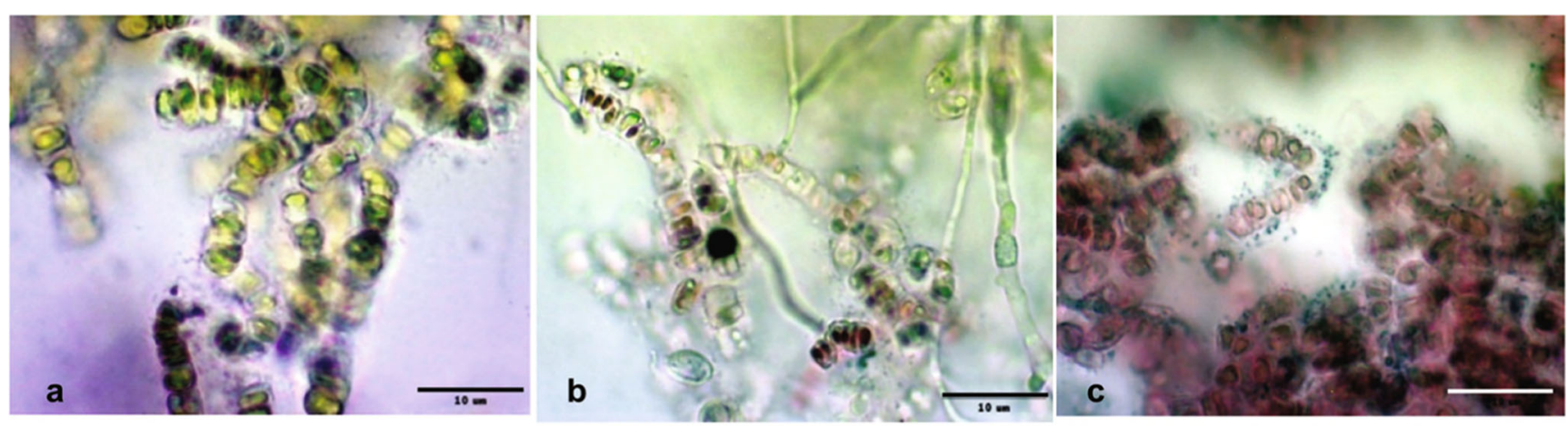

Fig. 3 Eolimna minima cells observed by light microscopy (scale bar $10 \mu \mathrm{m}$ ) after 7 days of exposure to a NP10, b NP50, and c NP100 solutions (respectively 20,50,100 $\mu \mathrm{g} \mathrm{KAuCl} / \mathrm{mL}$ ) corresponding to $\mathrm{KAuCl}_{4}$ solutions in Dauta medium with diatom suspensions

accumulation at NP50 on the inside edges of the wall. At these concentrations, diatom organelles such as the nucleus and chloroplasts were clearly visible and the cells appeared viable with well separated and structured organelles. For diatoms at NP100, AuNP uniformly occupied all of the intracellular space including within vital organelles such as the chloroplasts, causing the form of both cells and organelles to appear impaired with destructured content. Finally, no AuNP was detected in control tubes (Control20, Control50, and Control100) containing only culture medium and $\mathrm{KAuCl}_{4}$ solution.

\section{Discussion}

Several studies have shown that gold salts affect intracellular metabolism (Robinson et al. 1996; Hosea et al. 1986) and that $\mathrm{KAuCl}_{4}$-treated cells show a loss of chlorophyll fluorescence accompanied by a fall in carbon sequestration. These observations may be linked to the presence of AuNP in the chloroplasts, as seen here at the highest concentration. Thus, the reduction of $\mathrm{Au}$ (III) to non toxic $\mathrm{Au}(0)$ in nanoparticle form, would be a mechanism for cell detoxification (active or passive), but surprisingly no AuNP was detected within the vacuole, a storage organelle often involved in detoxification processes (Brembu et al. 2011; Nassiri et al. 1997). Yet, we must consider that the AuNP was made in the cell and then somehow released since no AuNP was detected in control tubes containing only culture medium and $\mathrm{KAuCl}_{4}$ solution. For low gold salt concentration (under $50 \mu \mathrm{g} / \mathrm{mL}$ ), the observed plasmon bands in Fig. 2a around 510-550 nm attest to the presence of gold in colloidal form with sizes in the range of 5-80 nm (Perrault and Chan 2009; Njoki et al. 2007). These colloidal dispersions are stabilized by electrostatic or steric forces which would be provided by ligands or macromolecules such as extracellular polymer substances present in the microenvironment. For high concentration (up to $100 \mu \mathrm{g} / \mathrm{mL}$ ), all the gold atoms would not be taken in charge and bigger particles and aggregates would be then formed. Indeed, the absorption spectra obtained with AuNP solely in Dauta medium or in the presence of diatoms are quite different. In addition to the maximum at $520 \mathrm{~nm}$, these broad bands display a secondary maximum around $620 \mathrm{~nm}$ from multipolar dielectric interactions traducing an aggregated state of gold colloids. Despite the large amounts of AuNP and the misshapen cells and organelles at the highest concentration, cells remained alive at all three salt concentrations, as indicated by the increase in $\mathrm{pH}$ after 7 days which attests to respiratory algal activity and thus diatom vitality. Indeed, it is known that during culture, $\mathrm{pH}$ tends to increase with the growth of algal

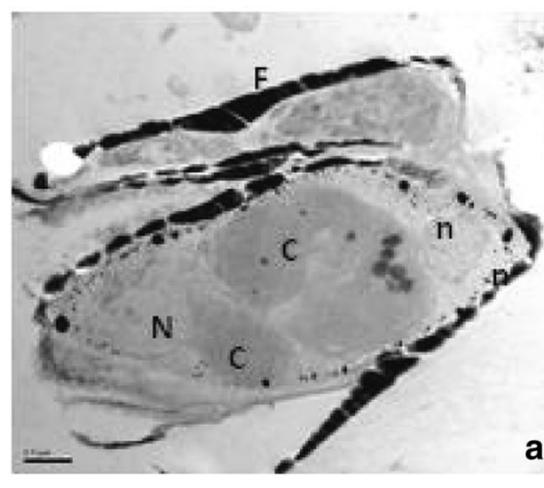

Fig. 4 TEM images of Eolimna minima (scale bar: respectively 0.5, 0.2, and $10 \mu \mathrm{m}$ ) after 7 days of exposure to a NP10, b NP50, and $\mathbf{c}$ NP100 solutions (respectively $20,50,100 \mu \mathrm{g} \mathrm{KAuCl}_{4} / \mathrm{mL}$ ) corresponding to
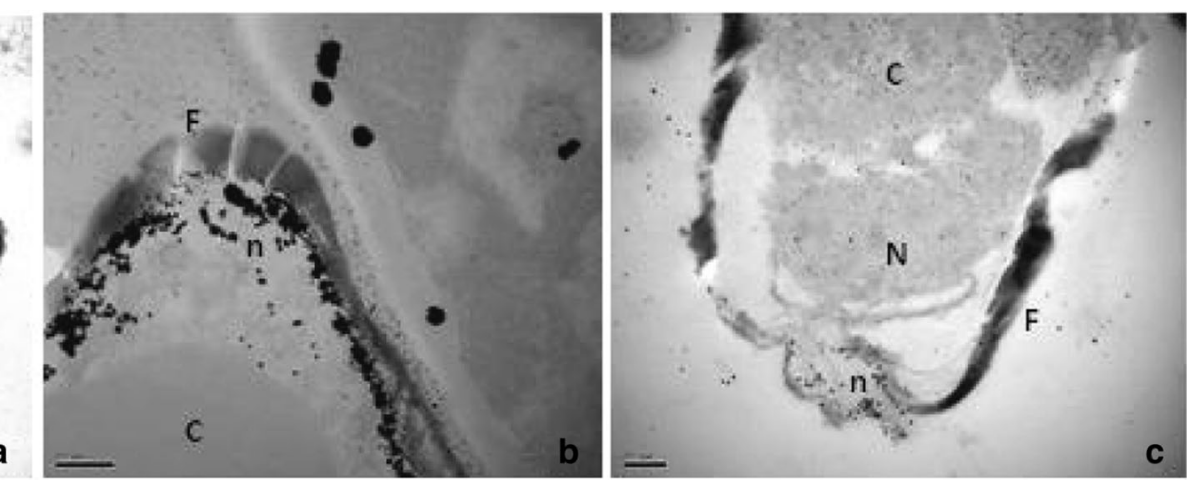

$\mathrm{KAuCl}_{4}$ solutions in Dauta medium with diatom suspensions. Details of cellular organelles ( $F$ frustule, $C$ chloroplast, $N$ noyau) and location of nanoparticules $(n)$ 
population that depletes the carbon oxide from the culture medium to perform photosynthesis processes. $\mathrm{pH}$ in culture medium may then reach values of 9 (Barsanti and Gualtieri 2014) that do not optimize the algal growth, but do not endanger its viability.

AuNP synthesis is not tolerated at the highest concentration but at the two lowest concentrations, it seems that AuNP are coated with biomolecules (sugars, proteins) which create a stable organic matrix around the particles and prevent their flocculation in the medium (which would be indicated by a blue color). At NP20, the small amount of AuNP synthesized by the cell and adsorbed on the plasma membrane did not appear sufficient to induce AuNP expulsion from the diatom cell. It appears different at NP50, as AuNP began to be visible outside the diatom cell. This could have resulted from AuNP being expelled/rejected through the pores of the diatom siliceous frustules or at the junction area between the two valves.

From a chemical point of view, we can suspect that within the cells, there is a reduction of the $\mathrm{KAuCl}_{4}$ solution by membrane proteins, not yet clearly identified (Gericke and Pinches 2006), to explain the observed AuNP biosynthesis. Recently, Schröfel et al. (2011) suggested various mechanisms of nanoparticle formation by living cells via the interaction of metallic salt with cellular organic compounds such as carbohydrates or proteins to reduce $\mathrm{Au}^{3+}$ to $\mathrm{Au}^{\circ}$ : (i) by oxidation of hydroxyl groups (abundant in polysaccharides of the algal cell wall) to carbonyl groups, (ii) by algal pigments rich in hydroxyl groups (fucoxanthins) or other highly reactive functional groups such as sulfhydryl present in the polysaccharides of the cell wall (fucoidans), and (iii) through the role of silaffin polypeptides. Although nitrogenase is recognized as able to reduce gold in cyanobacteria (Brayner et al. 2007), few enzymes or biomolecules have been identified as responsible for AuNP synthesis in algal extracts. Xie and co-workers (2007) reported synthesis of gold nanoplates in an algal extract and identified proteins as the primary reducing and shapedirecting agents. These single-crystalline gold nanoplates were produced by treating an aqueous solution of chloroauric acid with an extract of the unicellular green algae Chlorella vulgaris. A protein with a molecular weight of approximately $28 \mathrm{kDa}$ was isolated and purified by reversed-phase HPLC; it tested positive for the reduction of chloroauric acid in aqueous solution, and is suspected of performing the dual function of $\mathrm{Au}^{3+}$ reduction and size- and shape-controlled synthesis of gold nanocrystals. The isolated protein (named gold shapedirecting protein, GSP) was used to produce gold nanoplates with distinctive triangular and hexagonal shapes in high yields $(\sim 90 \%)$.

This work highlights the capacity of diatoms to synthesize AuNP while maintaining a state of cellular viability. Their ability to store AuNP raises questions concerning environmental impacts in freshwaters: e.g., the potential to stock AuNP intracellularly over time and its possible release into the aquatic environment. Indeed, diatoms have shown during this experience their potential to act as a bioreactor by synthetizing gold nanoparticles from gold salts. In case of even low gold salts contamination in natural freshwater environment, they could be suspected of playing the same role. The preponderant part of the diatoms in natural biofilms associated with their position at the basis of the trophic webs in rivers could then make them responsible for the contamination of their consumers (grazer animals) and consequently for the potential release of AuNP through the entire food web. Yet no data are currently available on AuNP quantification in aquatic ecosystems. To respond to these questions, further investigations are needed and these should first assess the quantification of AuNP bioaccumulation by diatoms for a concentration gradient of gold salts.

Acknowledgments The authors thank the Agence Nationale de la Recherche (ANR) which supported this work developed in the CITTOXIC Nano programme under the reference ANR 14 CE21 0001 01. They would also like to thank Bruno Etcheverria, from the EPOC laboratory (University of Bordeaux), for his support in laboratory work, and the Bordeaux Imaging Center which allowed us the access to their microscopic devices.

\section{References}

Barbaroux R, Meunier N, Mercier G, Taillard V, Morel JL, Simonnot MO, Blais JF (2009) Chemical leaching of nickel from the seeds of the metal hyperaccumulator plant Alyssum murale. Hydrometallurgy 100(1 2):10 14

Barsanti L, Gualtieri P (2014) Algae: anatomy, biochemistry, and biotech nology. CRC Press, Second Edition

Berbeco RI, Ngwa W, Makrigiorgos GM (2011) Localized dose enhance ment to tumor blood vessel endothelial cells via megavoltage $\mathrm{X}$ rays and targeted gold nanoparticles: new potential for external beam radiotherapy. Int J Radiat Oncol Biol Phys 81(1):270 276

Brayner R, Brayner R, Barberousse H, Hemadi M, Djedjat C, Yéprémian C, Coradin T, Livage J, Fiévet F, Couté (2007) Cyanobacteria as bioreactors for the synthesis of $\mathrm{Au}, \mathrm{Ag}, \mathrm{Pd}$ and $\mathrm{Pt}$ nanoparticles via an enzyme mediated route. A J Nanosci Nanotechnol 7(8):2696 2708

Brembu T, Jørstad M, Winge P, Valle K, Bones AM (2011) Genome wide profiling of responses to cadmium in the diatom Phaedactylum tricornutum. Environ Sci Technol 45(18):7640 7647

Corti CW, Holliday RJ, Thompson DT (2007) Progress towards the com mercial application of gold catalysts. Top Catal 44:331 343

Dauta A (1982) Conditions for phytoplankton development, a compara tive study of the behaviour of eight species in culture. II Role of nutriments: assimilation and intracellular storage. Annls Limnol 18: 217268

Gardea Torresdey JL, Parsons JG, Gomez E, Peralta Videa J, Troiani HE, Santiago P, Jose Yacaman M (2002) Formation and growth of $\mathrm{Au}$ nanoparticles inside live alfalfa plants. Nano Lett 2(4):397 401

Gélabert A, Pokrovsky OS, Schott J, Boudou A, Feurtet Mazel A, Mielczarski J, Mielczarski E, Mesmer Dudons N, Spalla O (2004) Study of diatoms/aqueous solution interface. I. Acid base equilibria, surface charge and spectroscopic observation of freshwater and ma rine species. Geochim Cosmochim Ac 68:4039 4058 
Gélabert A, Pokrovsky OS, Schott J, Boudou A, Feurtet Mazel A (2007) Cadmium and lead interaction with diatom surfaces: a combined thermodynamic and kinetic approach. Geochimet Cosmochim Ac 71:3698 3716

Gericke M, Pinches A (2006) Microbial production of gold nanoparticles. Gold Bull 39(1):22 28

Gong N, Kuishuang S, Wei F, Zhengzhi L, Changhua L, Yeqing S (2011) Biotoxicity of nickel oxide nanoparticles and bio remediation by microalgae Chlorella vulgaris. Chemosphere 83:510 516

Govindaraju K, Kiruthiga V, Kumar VG, Singaravelu G (2009) Extracellular synthesis of silver nanoparticles by a marine alga, Sargassum wightii Grevilli and their antibacterial effects. J Nanosci Nanotechnol 9(9):5497 5501

Guowu Z, Huang J, Du M, Abdul Rauf I, Ma Y, Li Q (2011) Green synthesis of $\mathrm{Au} \mathrm{Pd}$ bimetallic nanoparticles: single step bioreduction method with plant extract. Mater Lett 65(19 20): 29892991

He S, Zhang Y, Guo Z, Gu N (2008) Biological synthesis of gold nano wires using extract of Rhodopseudomonas capsulate. Biotechnol Prog 24:476 480

Hosea M, Greene B, McPherson R, Henzl M, Alexander D, Darnall DW (1986) Accumulation of elemental gold on the alga Chlorella vulgaris. Inorg Chim Acta 123(3):161 165

Korbekandi H, Iravani S, Abbasi S (2009) Production of nanoparticles using organisms. Crit Rev Biotechnol 29(4):279 306

Kovacs C, Kahlert M, Padisak J (2006) Benthic diatom communities along $\mathrm{pH}$ and $\mathrm{TP}$ gradients in Hungarian and Swedish streams. J Appl Phycol 18:105 117

Liz Marzan LM (2004) Nanometals: formation and color. Materials Today 7(2):26 31

Mandal D, Bolander ME, Mukhopadhyay D, Sarkar G, Mukherjee P (2006) The use of microorganisms for the application of metal nano particles and their application. Appl Microbiol Biotechnol 69:485 492

Mohanpuria P, Rana NK, Yadav SK (2007) Biosynthesis of nanoparti cles: technological concept and future applications. J Nanopart Res 10:507 517

Moradi AB, Swoboda S, Robinson B, Prohaska T, Kaestner A, Oswald SE, Wenzel WW, Schulin R (2010) Mapping of nickel in root cross sections of the hyperaccumulator plant Berkheya coddii using laser ablation ICP MS. Environ Exp Bot 69(1):24 31

Narayanan KB, Sakthivel N (2011) Green synthesis of biogenic metal nanoparticles by terrestrial and aquatic phototrophic and heterotro phic eukaryotes and biocompatible agents. Adv Colloid Interf Sci 169(2):59 79

Nassiri Y, Mansot JL, Wery J, Ginsburger Vogel T, Amiard (1997) Ultrastructural and electron energy loss spectroscopy studies of sequestration mechanisms of $\mathrm{Cd}$ and $\mathrm{Cu}$ in the marine diatom Skeletonema costatum. J C Arch Environ Contam Toxicol 33:147 155
Njoki PN, Lim IIS, Mott D, Park H Y, Khan B, Mishra S, Sujakumar R, Luo J, Zhong C J (2007) Size correlation of optical and spectroscop ic properties for gold nanoparticles. J Phys Chem C 111(40):14664 14669

Noll F, Sumper M, Hampp N (2002) Nanostructure of diatom silica sur faces and of biomimetic analogues. Nano Lett 2(2):91 95

Oberdörster G, Oberdörster E, Oberdörster J (2005) Nanotoxicology: an emerging discipline evolving from studies of ultrafine particles. Environ Health Perspect 113(7):823 839

Perrault SD, Chan CW (2009) Synthesis and surface modification of highly monodispersed, spherical gold nanoparticles of $50200 \mathrm{~nm}$. J Am Chem Soc 131(47):17042 17043

Pokrovsky OS, Feurtet Mazel A, Martinez RE, Morin S, Baudrimont M, Duong TT, Coste M (2010) Experimental study of cadmium inter action with periphytic biofilms. Appl Geochem 25:418 427

Renault S, Baudrimont M, Mesmer Dudons N, Gonzalez P, Mornet S, Brisson A (2008) Impact of gold nanoparticle exposure on two freshwater species: a phytoplanctonic alga (Scenedesmus subspicatus) and a benthic bivalve (Corbicula fluminea). Gold Bull 41(2):116 126

Robinson MG, Brown LN, Hall BD (1996) Effect of gold (III) on the fouling diatom Amphora coffeaformis: uptake, toxicity and interac tions with copper. Biofouling 11(1):59 79

Schröfel A, Kratosova G, Bohunicka M, Dobrocka E, Vavra I (2011) Biosynthesis of gold nanoparticles using diatoms silica gold and EPS gold bionanocomposite formation. J Nanopart Res 13(8): 32073216

Singaravelu G, Arockiamary JS, Ganesh Kumar V, Govindaraju K (2007) A novel extracellular synthesis of monodisperse gold nanoparticles using marine alga, Sargassum wightii Greville. Colloids and Surfaces B 57:97 101

Tedesco S, Doyle H, Redmond G, Sheehan D (2008) Gold nanoparticles and oxidative stress in Mytilus edulis. Mar Environ Res 66:131 133

Tedesco S, Doyle H, Blasco J, Redmond G, Sheehan D (2010) Exposure of the blue mussel, Mytilus edulis, to gold nanoparticles and the pro oxidant menadione. Comp Biochem Physiol C: Toxicol Pharmacol 151:167 174

Thakkar KN, Mhatre SS, Parikh RY (2010) Biological synthesis of me tallic nanoparticles. Nanomed Nanotechnol 6:257 262

Von Moos N, Bowen P, Slaveykova VI (2014) Bioavailability of inor ganic nanoparticles to planktonic bacteria and aquatic microalgae in freshwater. Environ Sci: Nano 1:214 232

Xie J, Lee JY, Wang DIC, Ting YP (2007) Silver nanoplates: from bio logical to biomimetic synthesis. ACS Nano 1(5):429 439

$\mathrm{Xu} \mathrm{ZP}$, Zeng QH, Lu GQ, Yu AB (2006) Inorganic nanoparticles as carriers for efficient cellular delivery. Chem Eng Sci 61(3):1027 1040

Zhang X, Yan S, Tyagi RD, Surampalli RY (2011) Synthesis of nanopar ticles by microorganisms and their application in enhancing micro biological reaction rates. Chemosphere 82:489 494 